\title{
The evaluation of archival maps in geohistorical research
}

\begin{abstract}
The array of archival maps from the $19^{\text {th }}$ and $20^{\text {th }}$ centuries is very large and, in order to assess their reliability for a particular analysis, some kind of evaluation form must be used. The proposed evaluation form comprises both formal and quantitative criteria, enriched with the maps' elaboration circumstances, which may influence their reliability. These factors are also applied at both the spatial and attribute levels of information. Guidelines include: the scope of content, the map's mathematical precision, the descriptive information correctness, the time reference of the content, and the information transfer efficiency.
\end{abstract}

Keywords

Historical GIS • historical geography • historical cartography • data quality - archival maps • map evaluation

(C) University of Warsaw - Faculty of Geography and Regional Studies
Tomasz Panecki

Department of Geoinformatics, Cartography and Remote Sensing, Faculty of Geography and Regional Studies, University of Warsaw, Poland e-mail: tpanecki@uw.edu.pl

Received: 20 March 2015

Accepted: 24 November 2015
Introduction

In the course of the last ten or twenty years it has been possible to observe not only a conspicuous trend connected with the growing interest in the spatial humanities and the renaissance of historical geography, but also the increasingly widespread access to Geographic Information Systems (GIS), which enable data gathering, processing and visualisation (Gregory \& Healey 2007). Geohistorical research and studies are understood in this paper as those exploring geographical patterns in the past as well as tracking changes in places through time, and often involve the application of archival maps, for example, in land use change analysis. The proper use of archival maps in the age of GIS still remains unresolved, which is strongly connected with the problem of map evaluation. The aim of the study is to propose a sort of evaluation form, which could potentially be used by researchers aiming to employ archival topographical maps in their studies. The criteria would apply to maps issued in the period of the $19^{\text {th }}$ century and first half of the $20^{\text {th }}$ century in Central Europe, especially for Polish lands.

The cartography of Polish lands during this period presents a special and unique case in Europe. Poland was divided between Austria, Prussia (Germany) and Russia in 1795 and did not exist as a sovereign state until 1918. Therefore, Polish lands were mapped by three different states using various map-making methods. These included projections and spheroids, inconsistent scales and methods of geographical reality modelling, along with symbology. Thus, it is crucial for these maps to undergo a critical evaluation prior to being used as a data source. This seems even more important when analysing maps elaborated at the same time in similar scales but by different "producers" (i.e. states).
Therefore, the evaluation criteria presented in this study can be applied to Austrian, Prussian and Russian maps from the $19^{\text {th }}$ century, as well as Polish cartographic materials from the $19^{\text {th }}$ century and first half of the $20^{\text {th }}$ century - namely, maps issued by the Military Geographical Institute (Polish: Wojskowy Instytut Geograficzny, WIG).

\section{Previous Works}

Evaluations of maps and the quality of data they provide has been a frequent research topic. Just before the Second World War, Eckert (1939) formulated the rules and criteria of map evaluation: precision, completeness, purpose, veracity, comprehension, legibility and beauty. Conversely, according to Boczarov (1966), map evaluation can be conducted on two levels: the map's content and the map's form. Evaluation of the content is based on the reliability, relevance, structure and scope of the content, but also on the degree of the map's detail and the adequacy of information choice according to the map's purpose. Meanwhile, evaluation of the form touches issues such as legibility, reference qualities, precision in terms of visual apparatus adequacy, and the graphic and numeral load of the map. Another Russian cartographer, Salishchev (1984), approaches map evaluation in terms of the map's mathematical precision, inclusive of the content, and the correctness of reality representation (i.e. accuracy of generalization), scientific value, and political orientation (sic!). Ostrowski (1979) emphasised the necessity of distinguishing the criteria according to the aim of the map. Maps elaborated for scientific purposes should be evaluated in terms of level of detail, fidelity and precision. 
The criteria for those used for purely practical reasons (e.g. road atlases) should involve reliability, legibility and usability. Psychological orientation and visual impact should be taken under consideration for maps used in didactics. There are also general rules which include the map's legibility and the adequacy of the content to be depicted.

Map evaluation has also been the subject of historical geography research. Buczek formulated some rules defining the evaluation of archival maps as a historical source. First and foremost, the map should be assessed in the context of its potential credibility, taking into consideration the time and circumstances of its creation, as well as the author. Buczek also pays attention to the technical side of map elaboration, i.e. legend construction, symbol system and sheet division. A very important element is the analysis of mathematical foundations and the level of detail. The next step involves the analysis of content depiction in terms of credibility, by comparing its representation to other maps and written sources (registers, descriptions, etc.). A combination of the above-mentioned elements was the foundation of the "archival maps evaluation form" which should be used in all geohistorical studies (Buczek 1974).

Archival map evaluation also falls under the scope of geographers, especially those focusing on cultural landscape transformations over time. One such study focused on the comprehensive assessment of a set of maps dating from the $17^{\text {th }}$ to the $20^{\text {th }}$ century. The maps were analysed according to certain criteria exemplifying such features as content depiction, mathematical precision and legibility. Next, quantitative methods were used to assess and classify those maps with strongly qualitative characteristics (e.g. good/bad legibility). As a result, respective qualitative values were assigned to each of the map characteristics individually. In effect, the maps were ordered form "worst" (Helwig's map from the $17^{\text {th }}$ century) to "best" (a Polish tactical map elaborated by WIG at the beginning of the $20^{\text {th }}$ century) (Nita \& Myga-Piątek 2012).

This concept, though seemingly attractive, is not devoid of shortcomings. Firstly, the use of a quantitative method appears dubious, as it changes the data measurement level from nominal/ ordinal to a ratio scale, raising (only seemingly!) the objectivity of the data. Secondly, the authors treated the analysis of map content superficially by omitting a division into separate thematic layers. Thirdly, it also appears erroneous to apply the same criteria to maps from the $17^{\text {th }}$ and $20^{\text {th }}$ centuries without taking into consideration the historical conditions and evolution of cartography. For instance, Helwig's map cannot be equally mathematically accurate to the WIG topographic map, since precise measurement methods had not been invented at the time. For the same reason, Helwig's map cannot have an equally wide extent of content to newer maps, since the reality modelled and depicted by cartographers changed with the course of the development of technology and civilisation.

The comparison of "old" and "new" archival maps and their submission to analysis according to the same measures seems inappropriate. What is more, one map should not be considered better than another just because it is newer. A map's correctness and opulence are dictated by the time of its elaboration. Furthermore, the $18^{\text {th }}$ century geohistorical landscape can only be depicted by a map from that time. Therefore, some objective criteria (e.g. mathematical precision) may indicate that a map is less adequate than newer ones, but taking it into consideration for particular analysis seems necessary nonetheless. Consequently, the overall evaluation of archival maps should be directed at identifying their strengths and weaknesses in the context of the analysis to be conducted. Comparisons between maps elaborated in different periods should also be avoided.

\section{The evaluation criteria}

In order to establish a consistent archival map evaluation form and to assess its reliability, it is necessary to set up the form's theoretical foundations. First of all, a distinction between the formal criteria and the circumstances of map elaboration must be made. The nature of the criteria-based approach is mostly quantitative and requires assessing such aspects as the map's mathematical precision or number of depicted categories. On the other hand, the circumstances of map elaboration also have a significant impact on the evaluation process as they play an explanatory function. The reason for a map's creation affects its scope of content (number of categories) and the methods of field measurement influence the map's mathematical precision. Therefore, one should keep in mind that an archival map can only be as accurate as the circumstances of its elaboration allow.

Secondly, maps present two levels of information: spatial (or geographic), which refers to object location, and attribute (descriptive), corresponding with an object's characteristics. The reliability of these levels can be evaluated, but it is important to address particular criteria to the related level of information. However, the levels cannot be separated completely because they affect each other, as proven by map generalization, which influences both the spatial and attribute map aspects (e.g. object displacement and reclassification).

The map evaluation criteria and their elaboration circumstances, as well as the levels of map reliability they concern, are depicted in table 1. The selection of criteria for archival map analysis is mostly derived from previous works, although the most important aspect of the study was to distinguish the elaboration circumstances from the formal criteria and to assess them according to either spatial or attribute map reliability.

Although the evaluation form is designed to be universal, the most important factor is the aim of the map elaboration and analysis objective. Following the approach of Ostrowski (1979), the choice and weighting of the criteria should be connected with the aim of the conducted analysis and map elaboration objective, which in this case are the circumstances (tab. 1). The idea behind the proposed system is to equip the researchers with the apparatus to evaluate the map utility in the context of the particular research aims, which would make the approach more systematic and formalised. This enables the map to be evaluated differently depending on different research goals. For example, in the case of a natural landscape, such as hydrography, what seems very important is a large map scale, river system and land relief depiction details. On the other hand, to reconstruct administrative divisions, a detailed representation of administrative borders at each level seems more important. The reason for archival map elaboration is a crucial factor as well. Although topographic maps can be used for almost any type of analysis, researchers must be aware of the differences between them, since they were designed particularly to serve military purposes (Russian verst maps from the end of the $19^{\text {th }}$ century), as well as civil and state management (Austrian Spezialkarte or Polish WIG maps).

The scope of a map's content can be understood as a formal criterion (number of categories in thematic layers) and a circumstance (content classification methods). As it is a result of cartographical modelling, its rules and methods are not known to the contemporary user, which may lead to a number of obstacles in the process of evaluation and understanding content. Maps' semiotic foundations cannot be fully understood, especially where content classification is concerned - for example, disparate and incomparable road categories, different classification of settlements, inconsistent depiction of physiography, etc. These issues apply to archival as well as contemporary maps (Kent \& Vujakovic 2009; Panecki 2014). 
MISCELLANEA GEOGRAPHICA - REGIONAL STUDIES ON DEVELOPMENT

Vol. $19 \cdot$ No. 4 • 2015 • pp. 72-77 • ISSN: 2084-6118 • DOI: 10.1515/mgrsd-2015-0027

Table 1. Proposition for an archival maps evaluation form. Particular factors can be considerered as formal criteria, or a map's elaboration circumstances, and can address a map's spatial or attribute level of information

\begin{tabular}{|c|c|c|c|c|c|}
\hline & \multirow{2}{*}{ Criterion } & \multirow{2}{*}{$\begin{array}{l}\text { Circumstance } \\
\text { Spatial }\end{array}$} & \multicolumn{2}{|c|}{ Level of reliability } \\
\hline & & & & Attribute & \\
\hline \multicolumn{2}{|c|}{$\begin{array}{l}\text { Aim of the map elaboration and analysis } \\
\text { objective }\end{array}$} & - & + & + & + \\
\hline \multirow{2}{*}{ Scope of content } & $\begin{array}{l}\text { Number of } \\
\text { categories }\end{array}$ & + & + & - & + \\
\hline & $\begin{array}{l}\text { Classification } \\
\text { methods }\end{array}$ & - & + & - & + \\
\hline \multicolumn{2}{|c|}{ Mathematical precision } & + & + & + & - \\
\hline \multicolumn{2}{|c|}{ Descriptive information correctness } & + & + & - & + \\
\hline \multirow{2}{*}{$\begin{array}{l}\text { Time reference of } \\
\text { the content }\end{array}$} & $\begin{array}{l}\text { Time issue } \\
\text { uniqueness }\end{array}$ & - & + & + & + \\
\hline & $\begin{array}{l}\text { Updates and } \\
\text { reprints }\end{array}$ & - & + & + & + \\
\hline \multirow{2}{*}{$\begin{array}{c}\text { Information transfer } \\
\text { efficiency }\end{array}$} & $\begin{array}{l}\text { The condition of the } \\
\text { map }\end{array}$ & - & + & + & + \\
\hline & $\begin{array}{l}\text { Legibility and } \\
\text { graphic design }\end{array}$ & - & + & + & + \\
\hline
\end{tabular}

The main source of topographic map content reconstruction is the analysis of the map legend, which can exist in a number of variants, especially in the case of serial archival maps issued over several years. Thus, it is impossible to assign one set of symbology to all map series. This applies, in particular, to topographic maps elaborated at the turn of the $19^{\text {th }}$ and $20^{\text {th }}$ centuries, such as the Austrian Spezielkarte 1:75 000 (Faluszczak 2011) or the German Karte des Deutches Reiches 1:100 000 (Pasławski 1967), where the scope of content changed over time; consequently, a number of different legend versions exist. In analysing this type of map, it is important to remember to use a legend consistent with the particular map sheet. In other words, the date of issue of the legend and the particular map sheet should be similar (Panecki 2014). Another problem can be posed by the abbreviations present on the maps. These should be treated as a cartographical symbol, as they carry specific information - for example, about the detailed characteristics of an object (factory, cemetery, building, etc.). Abbreviations are classified as an element of a map's content and are also presented in the legend. However, according to Gasiewicz (1930), all abbreviations are in fact permissible, as long as they leave no doubt in their explication.

Number of categories in thematic layers: One of the most important elements in the evaluation of the informative potential of archival maps is not the overall number of presented categories, but the inclusion of particular thematic layers in the calculations. This enables the map to be accessed for the depiction of a specific thematic category, such as road networks, settlement networks or hydrography. This can be considered as both a formal criterion (quantitative characteristic) and a circumstance, as maps can depict different numbers of features depending of their aim or time of elaboration.

Topographic maps (archival included) present a complex image of geographical reality, which comprises the landscape elements that are important from a military or administrative point of view (Libiński 1912; Carlock 1916). These maps are a basic source of data for geohistorical landscape reconstruction, which can be divided into an array of layers including: settlements and built-up areas, transport networks, facilities, other anthropological objects, administrative and political borders, hydrography, vegetation and relief (Arnold 1951; Naylor 2006).
Map content division into categories with respect to the number of elements allows the detailed assessment of the informative potential of the map. However, the objects depicted on the map can have a double function, such as a farm (a settlement and a facility) or a river (hydrography and transport). In this case, the major function has to be identified as the object to be ascribed to the appropriate category. Sometimes, when comparing several maps, it is necessary to generalize original categories in order to make them comparable. For instance, comparing afforestation from Perthees maps (Mapy szczegulne wojewodztw [Detailed Maps of Voivodeships], 1:225 000, end of $18^{\text {th }}$ century) with the Quatermaster's map $(1: 126000,1839)$ involved the aggregation of "dense woods" and "rare woods" (Quatermaster's map) into the "woods" category (Perthees) (Plit 1996).

Classification methods in thematic layers: The comparison of changes occurring in the geohistorical landscape by analysing archival maps requires a deep insight into the methods of content classification. This includes the question of how particular thematic layers were ordered and distinguished between - for example, road networks (functional or administrative criteria, importance of the road, its width), vegetation (types of division, evergreen forest, deciduous forest), or settlements (size, administrative affiliation, type). Addressing that problem could involve archival cartography handbook studies, which often describe the rmethods of cartographic modelling (Libiński 1912; Carlock 1916; Kreutzinger 1928). Directing attention to these elements will not, however, resolve this issue, but may sensitise the researcher to potential inconsistencies. The problem can be partially solved by the elaboration of a standardized symbol classification for the set of analysed maps; however, this type of action exceeds the simple usability analysis (Dukaczewski 2005; Panecki 2014).

The analysis of archival maps' mathematical foundations has been a common subject of interest among researchers, who have typically been concerned with scale determination along with it volatility, object location errors and azimuth errors. Although it may be considered a formal and quantitative criterion, a map's precision is also a result of the circumstances if its elaboration (time of issue, producer, methods of field measurements). Studying these factors can also be considered a research goal - for example, answering the question of why similar maps from the same period are characterized by different levels of precision. 
One of the simplest and most effective methods of the evaluation of a map's mathematical correctness is the analysis of point location errors based on measuring the distance between the chosen points on the archival map and the reference material. Thanks to this method, an absolute error (in metres) or relative error (percentile relation to actual distance) can be calculated. Furthermore, measurement points can result in an overall table of distance errors or can be used to interpolate isolines (Hooke \& Perry 1976). The assessment of a map's mathematical precision is crucial in order to evaluate its reliability in relation to the digitization process (Szady 2008). Furthermore, mathematical error has to be assessed in the context of analysis and the general rules of geographic data accuracy - maps with e.g. $250 \mathrm{~m}$ error can be used in a 1:500 000 scale of analysis (Goodchild 1993). To sum up, the array of works related to maps' mathematical precision is wide and includes both international (Hooke \& Perry 1976; Govedarica \& Borisov 2011; Jenny \& Hurni 2011) and Polish authors who specify their interest in maps covering Polish lands (Szeliga 1968; Konias 1984; Krzywicka-Blum 1994).

The reliability of archival maps is related not only to the accuracy of object location (mathematical precision), but also to attribute relations between real objects and their map instances (descriptive information correctness). While the mathematical accuracy is relatively easy to interpret, the evaluation of cartographic modelling conducted by a cartographer in the past is significantly more complicated. It requires in-depth analysis of the map content and historical landscape, based on written sources such as indexes, registers or gazetteers and other maps. For example, the Quartermaster's map $(1: 126000,1839)$ can be compared with Tabella miast, wsi, osad Królestwa Polskiego [Tables of cities, villages and settlements of the Kingdom of Poland] (1827). A city depicted by a particular symbol referring to a certain number of inhabitants does not necessarily have to be inhabited by this amount of people (Szady 2008). Descriptive information correctness is not only about studying a particular map's content elements, but is also connected with a map's elaboration circumstances and the reasons behind certain level of correctness.

Although the reliability assessment is likely to involve some "case study" analysis, there are several indications that allow map reliability to be estimated. Analysis of the type of data sources is necessary: if a map was elaborated via direct field measurements, the generalization of materials belonging to the map producer or those provided by others should be considered. It can be stipulated that the maps with the highest credibility are those based directly on field measurements. This set of maps comprises reproductions of topographic surveys: Austrian (1:28 800 up to 1869 and 1:25 000 from 1869), Prussian (1:25 000) and Russian (1:21 000) (Krassowski 1973; Timár et al. 2006; Konias 2010). Maps in approx. 1:100 000 scales (Polish tactical maps by WIG, Austrian Spezialkarte, or German Karte des Deutches Reiches) were based on topographic surveys as well as office-based work (Krassowski 1973).

The second level of credibility involves maps based on the author's own materials and those elaborated in the process of cartographic generalization. These are the topographic and general maps where the sources of data are topographic maps by the same printer/author, such as the Austrian Generalkarte von Mitteleuropa (1:200 000) or the German Topographische Übersichtskarte des Deutschen Reiches (1:200 000). When the primary data source encompasses materials elaborated by the same author or institution, it can be assumed that they share common classification methods and similar cartographic symbols.

The third level of credibility is met when the data source was prepared by external authors. This concerns general maps, like the Polish Karta Dawnej Polski 1:300 000, elaborated in Paris by Wojciech Chrzanowski on the basis of partition maps. Even the large-scale German Karte des Westlichen Russlands (1:100 000 ), representing the area of the western part of Russia before the First World War, should be treated carefully as it was based on Russian topographic maps and the (already at the time) obsolete Reymann's map (Krassowski 1973). The same concerns the sheets of the Austrian Spezialkarte (1:75 000), which cover the area outside of Austria-Hungary. Basing maps solely on materials of foreign origin meant the reinterpretation of the cartographical depiction of geographical space, which, for the cartographer elaborating the map, was not necessarily self-explanatory or comprehensible due to the differences in landscape modelling by German and Russian cartographers. In practice, this may mean that the classification of the objects is incorrect.

The reliability of data on maps may also be connected with deliberate forging. Little is known about this deliberate falsification before 1945, although it was mentioned by Col. J. Kreutzinger - the chief of WIG - who claimed there were in fact cases of mistakes or error, even though "the deliberate falsification had no raison d'etre" (Kreutzinger 1928).

The time reference of map content represents the elaboration circumstances affecting both spatial and attribute data reliability. The preparation of a map sheet at a particular time in the past does not necessarily mean that all of the map elements are updated for that date. Establishing the actual time of data update requires a very detailed map analysis, which may involve comparing objects with a known time of origin (or destruction) with their instances on the map. However, prior to this in depth analysis, an approximate time of update can be determined by the map's date of issue.

Map time issue uniqueness: Another worthwhile question is the uniqueness of the map's time of issue compared to others covering the same area in a similar scale. Therefore, a map which fills a time gap between others is worth analysing despite its potential shortcomings, such as distortions or a low number of objects depicted. For example, the manuscript Gilly-Cron map from 1793 has low mathematical precision (c.a. 300 m) and lacks a map legend; however, its high level of detail (scale approx. 1:50 000 ) and time of issue enables researchers to study the area of German Südpreußen (South Prussia) (Scharfe 1972; Konias 2010).

Updates and reprints: A map update would seem to be a clear advantage as it maintains the same area covered, content classification methods and mathematical foundations with an updated reality depiction. It allows the observation of the changes occurring in the geohistorical landscape through the years while maintaining the same or similar semantic guidelines and premises. One example is the Austrian map Königreich Galizien und Lodomerien: herausgegeben im Jahre 1790 (1:288 000), also known as "the Liesganig map" (after the author, Joseph Liesganig), which was reissued and updated a number of times up until the second half of the $19^{\text {th }}$ century (Faluszczak 2011).

Information transfer efficiency can also be considered as a particular circumstance influencing spatial and attribute map aspects.

The condition of the map: The information transfer, understood as ease and efficiency of reading and acquiring the spatial and attribute data from the map, is mainly a result of the condition of this historical document. Above all, this concerns the "older" archival maps, frequently elaborated as manuscripts or printed in a limited number of copies, as their colour could have been distorted or the map itself could have shrunk or got torn (Jutrzenka-Supryn 2008).

An extreme case of a badly-preserved map is the map of Greater Poland by Ernest Gaul from the beginning of the $19^{\text {th }}$ century. It was printed in colour, but as unfinished manuscripts, 
and it got burnt during the Second World War in the fire which burnt down the Raczynski Library in Poznań. Currently, it is only possible to access its black-and-white photocopies from the interwar period (Żyszkowska 2012).

Legibility and graphic design: Proper map analysis is inseparably linked to the correct decoding of information in order to avoid cartographic symbol misinterpretations in the process of storing data in the geodatabase (vectorization) (Wolski 2012; Wong, So, Zhang 2012). A legible and clear system of map symbols and the proper use of visual variables minimises the potential errors, while graphic overload generates difficulties with reading the map (Bertin 1967). For instance, elaborated in black-andwhite, the printed copies of the Austrian Spezialkarte (1:75 000), whose range of information is very rich, prove to be illegible. Mountainous areas, where the relief is depicted with contour lines and hachures, along with the forest presentation, results in a graphically complicated depiction which is difficult to interpret.

\section{Summary}

Evaluating the reliability of archival maps is a complex process requiring not only the analysis of an array of formal criteria, but also paying attention to the maps' elaboration circumstances, which affect various aspects, including mathematical precision, scope and content correctness. It is also crucial to address the above-mentioned factors properly in terms of the spatial or attribute level of data, as for some research goals these levels (although connected to each other) are not equally important. Table 1 clearly shows that, when it comes to archival maps, their elaboration circumstances play a more important role in assessing the maps' reliability than formal and qualitative criteria.

A final question considering the consistency (or flexibility) of the proposed evaluation form should be posed. Should scholars use a consistent and stable evaluation criteria system which may provide a more coherent result, or should it instead be flexible and adjustable towards particular research goals? Three approaches seem possible in this case. Firstly, no specific or consistent array of criteria can be established and each map should be treated and evaluated individually, since it is a unique historical document and may be the basis for various analyses. Secondly, we can set an array of criteria which can differently weighted and used. In general, maps should be evaluated on a similar basis, although certain criteria can be underlined (or dropped) if the aim of the study requires it. Lastly, a firm set of criteria can be established and all maps should be evaluated using the same basis, with no exceptions. Therefore, it could be possible to clearly state which maps are 'good' and which are 'bad', no matter what the purpose of analysis or elaboration circumstances.

\section{References}

Arnold, S 1951, Geografia historyczna Polski, Państwowe Wydawnictwo Naukowe, Warszawa.

Bertin, J 1967, Sémiologie graphique, Paris, Mouton/GauthierVillars.

Boczarow, MK 1966, Osnowy tieorii projektowania sistiem kartograrficznych znakow, Moscow.

Buczek, K 1974, 'Stan i potrzeby badań nad dziejami kartografii polskiej' in Materiały na III Konferencję poświęconą naukom pomocniczym historii, ed J Szymański, Problemy nauk pomocniczych historii, Katowice, pp. 143-157.

Carlock, FD 1916, Military Topography and Photography, George Banta Publishing Company.

Dukaczewski, D 2005, 'Elektroniczna mapa animowana Gór Izerskich', Polski Przegląd Kartograficzny, vol. 37, no. 1, pp. 23-36.

Eckert, M 1939, Kartographie; Ihre aufgaben und bedeutung für die kultur der gegenwart, W. de Gruyter \& Co., Berlin.

Faluszczak, FP 2011, Kartografia Galicji Wschodniej w latach 1772-1914, Wydawnictwo Uniwersytetu Rzeszowskiego, Rzeszów.

Gąsiewicz, S 1930, Znaki topograficzne map, Główna Księgarnia Wojskowa, Warsaw.

Goodchild, MF 1993, 'Data models and data quality: problems and prospects' in, eds MF Goodchild, B Parks \& L Steyaert, Environmental Modeling with GIS, Nowy Jork, Oxford University Press, pp. 94-103.

Govedarica, M \& Borisov, M 2011, 'The analysis of data quality on topographic maps', Geodetski vestnik, vol. 55, no. 4, pp. $713-725$.

Gregory, IN \& Healey, RG 2007, 'Historical GIS: structuring, mapping and analysing geographies of the past', Progress in Human Geography, vol. 31, no. 5, pp. 638-653.

Hooke, J \& Perry, RA 1976, 'The Planimetric Accuracy of Tithe Maps', The Cartographic Journal, vol. 13, no. 2, pp. 177183.

Jenny, B \& Hurni, L 2011, 'Studying cartographic heritage: Analysis and visualization of geometric distortions', Computers \& Graphics, vol. 35, no. 2, pp. 402-411.
Jutrzenka-Supryn, D 2008, 'Materiały i techniki wykonywania map od starożytności do XVIII wieku' in Z dziejów kartografii, eds S Alexandrowicz \& R Skrycki, Dawna mapa źródłem wiedzy o świecie, Szczecin, pp. 71-85.

Kent, A \& Vujakovic, P 2009, 'Stylistic Diversity in European State 1:50 000 Topographic Maps', The Cartographic Journal, vol. 46, no. 3, pp. 179-213.

Konias, A (1984) 'Metody oceny dokładności dawnych map', Materiały Ogólnopolskich Konferencji Kartograficznych in Lublin, pp. 64-76.

Konias, A 2010, Kartografia topograficzna państwa i zaboru pruskiego od II połowy XVIII wieku do połowy XX wieku, Wydawnictwo Naukowe Akademii Pomorskiej, Słupsk.

Krassowski, B 1973, Polska kartografia wojskowa 1918-1945, Wydawnictwo MON, Warsaw.

Kreutzinger, J 1928, Topografja. Pomiar i zdjęcie kraju, kartografja $i$ wojskowe znaczenie terenu, Wojskowy Instytut Geograficzny, Warsaw.

Krzywicka-Blum, E 1994, 'Nowa metoda analizy i prezentacji zmienności skali dawnych map dużych obszarów', Polski Przegląd Kartograficzny, vol. 26, no. 2, pp. 75-84.

Libiński, H 1912, Jak czytać austriackie mapy wojskowe $i$ orientować się za ich pomocą $w$ terenie?, Księgarnia Gebethner i Spółka, Kraków.

Naylor, S 2006, 'Historical geography: natures, landscapes, environments', Progress in Human Geography, vol. 30, no. 6 , pp. $792-802$.

Nita, J., Myga-Piątek, U. 2012, 'Rola GIS w ocenie historycznych opracowań kartograficznych na przykładzie Wyżyny Częstochowskiej' in Prace Komisji Krajobrazu Kulturowego, eds J Plit \& J Nita, Źródła kartograficzne w badaniach krajobrazu kulturowego, Sosnowiec, Komisja Krajobrazu Kulturowego Polskiego Towarzystwa Geograficznego, pp. 116-135.

Ostrowski, W 1979, 'Semantyczny aspekt sprawności mapy', Prace i Studia Geograficzne, no. 1, pp. 153-224.

Panecki, T 2014, 'Creating a common symbol classification for a new historical geoportal of Poland', Miscellanea Geographica, vol. 18, no. 4, pp. 34-40. 
Pasławski, J 1967, 'Mapa topograficzna 1:100 000 Polski zachodniej i północnej wydana w drugiej połowie XIX wieku', Przegląd Geodezyjny, vol. 39, pp. 7-13, 68-72, 108-111.

Plit, J 1996, 'Antropogeniczne i naturalne przeobrażenia krajobrazów roślinnych Mazowsza (od schyłku XVIII w. do 1990 r.)', Prace Geograficzne PAN, vol. 166, pp. 7-140.

Saliszczew, K 1984, Kartografia ogólna, Państwowe Wydawnictwo Naukowe, Warszawa.

Scharfe, W 1972, Abriss der Kartographie Brandenburgs 17711821, Walter de Gruyter, Berlin, New York.

Szady, B 2008, 'Zastosowanie systemów informacji geograficznej w geografii historycznej', Polski Przegląd Kartograficzny, vol. 40, no. 3, pp. 279-283.

Szeliga, J 1968, 'Analiza dokładności wybranych map wybrzeża polskiego z XVII i XVIII wieku', Zeszyty Geograficzne Wyższej Szkoły Pedagogicznej w Gdańsku, vol. 10, 37-85.

Timár, G, Molnár, G, Székely, B, Biszak, S, Varga, J and Jankó, A 2006, Digitized maps of the Habsburg Empire - The map sheets of the second military survey and their georeferenced version, Arcanum, Budapest.
Warszawa Tabella miast, wsi, osad Królestwa Polskiego, z wyrażeniem ich położenia i ludności, alfabetycznie ułożona w Biórze Kommissyi Rządowéy Spraw Wewnętrznych i Policyi, 1827 [Online]. Available from: <http:// bc.wbp.lodz. pl / dlibra/ doc metadata?id=17882\&from=publication $>$.

Wolski, J 2012, 'Błędy i niepewność w procesie tworzenia map numerycznych' in Prace Komisji Krajobrazu Kulturowego, eds J Plit \& J Nita, Źródła kartograficzne w badaniach krajobrazu kulturowego, Sosnowiec, Komisja Krajobrazu Kulturowego Polskiego Towarzystwa Geograficznego, pp. 15-32.

Wong, DW \& So, BKL \& Zhang, P 2012, 'Addressing quality issues of historical GIS data: an example of Republican Beijing', Annals of GIS, vol. 18, no. 1, pp. 17-29.

Żyszkowska, W 2012, 'Mapa Departamentu Poznańskiego Edwarda Raczyńskiego jako źródło $w$ badaniach stanu i zmian środowiska Wielkopolski' in Biblioteka Polskiego Przeglądu Kartograficznego, eds B Konopska, J Ostrowski, J Pasławski \& PE Weszpiński, Dawne mapy jako źródła historyczne, Warszawa, pp. 36-44. 